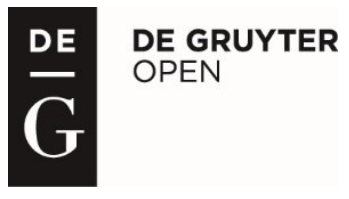

LEGE ARTIS

Language yesterday, today, tomorrow

Vol. III. No 12018

\title{
INTERMEDIALITY AND POLYMORPHISM OF NARRATIVES \\ IN THE GOTHIC TRADITION
}

\section{Zoia Ihina}

\section{Kyiv National Linguistic University, Kyiv, Ukraine}

Ihina, Z. (2018). Intermediality and polymorphism of narratives in the Gothic tradition. In Lege artis. Language yesterday, today, tomorrow. The journal of University of SS Cyril and Methodius in Trnava. Warsaw: De Gruyter Open, 2018, III (1), June 2018, p. 80-123. DOI: 10.2478/lart2018-0003 ISSN 2453-8035

\begin{abstract}
This article deals with polymorphous features of Gothic narratives seen as stories about supernatural events. Polymorphism reveals itself as a property of a narrative to be reinterpreted in the same medium or in different ones, and the main event is thus retranslated either authentically (in detail or in a reduced form) or with modifications of the form and content of the original. The article also suggests a classification of polymorphous Gothic narratives.
\end{abstract}

Key words: event, Gothic, intermediality, narrative, polymorphism, retranslation.

\section{Introduction}

Narratives belonging to the Gothic tradition, or Gothic narratives, make up a separate type of narratives characterized by specific features that set them apart from other types. These specificities are connected with tanatological aesthetics of the unwelcome, or the macabre aesthetics (Ниббриг 2005: 22; Morgan 2002: 67) that realizes the Gothic myth - a complicated artistic phenomenon exposing the peculiarities of the literary Gothic tradition, an aesthetic body of narrative texts based on the ideological themes topical for the $18^{\text {th }}$ century literature (Заломкина 2011: 4, 19, 88). In modern culture, the literary Gothic tradition has traversed the 
borders of literature and is successfully exploring the domains of cinema, theatre, music, happening, advertisement, performance (Cavallaro 2002: 1), etc. It is known under the common name the Gothic.

The theory of narrative (narratology) reveals universal features immanent to the texts recounting events; it studies them in two aspects - as stories (the "what" narrative, or the narrated) and as discourses (the "how" narrative, or the manner of telling) (Toolan 2006: 460). In this article, narrative is treated according to Schmid - as a story illustrating an event, i.e. the primary feature of any narrative is eventfulness (the necessity of an event). The event causes changes in a situation, the latter being a sum total of circumstances that create the background of a certain story. The event may be physical (external) or mental (internal). Physical events concern outer changes in the situation; mental events consist in psychic transformations of the living entities involved (Schmid 2010: 8-9). Both types of events are described by the formula suggested by Danto (Данто 2002: 223):

If any situation is represented in any narrative as an initial state $(F)$ of something or somebody $(x)$ at a certain moment of time $\left(t_{1}\right)$, this situation may be changed if something $(H)$ happens to $x$ at $t_{2}$ after $t_{1}$, and in the issue $x$ changes its state ( $F$ into $G$ ) after $t_{2}\left(a t t_{3}\right)$. Thus, if $x$ is $F$ at $t_{1}$, and $H$ happens to $x$ at $t_{2}$, then $x$ is $G$ at $t_{3}$.

The physical event illustrated by the narrative fragment below (Perkins Gilman 1998: 9) is encountering something unfamiliar - an ornate wallpaper pattern never seen before. The mental event is a series of transformations (At night in any kind of light) of that pattern into bars keeping a woman captive. While the gaudiness of the wallpaper may well be perceived objectively, the narrator sees the described pattern for the first time, the idea of a woman behind that pattern as if behind bars, refers to the internal sphere of imagination. Thus, $x$ is the narrator contemplating the 
yellow wallpaper $(F)$ at daytime $\left(t_{1}\right)$. At night $\left(t_{2}\right)$ powers of imagination stir $(H)$ the narrator $(x)$, and $\mathrm{s} /$ he $(x)$ sees the woman $(G)$ after that $\left(t_{3}\right)$ :

The wallpaper was not arranged on any laws of $<\ldots>$ symmetry, or anything else that I ever heard of. $<\ldots>$ At night in any kind of light $<\ldots>$ it becomes bars! The outside pattern I mean, and the woman behind it is as plain as can be $<\ldots>$ I am quite sure it is a woman (Perkins Gilman 1998: 9).

The narrative above represents the literary Gothic tradition (the Gothic) where the main event is based on specific circumstances that enable the encounter of two opposing forces - the known and the unknown, the latter heavily relying on the ideas of the supernatural. The hypothesis of this confrontation as the essence of the Gothic is discussed in Paragraph 3 of this article. The emergence of the supernatural in the quoted story "The yellow wallpaper" is qualified as the mental event that takes its source in the narrator's imagination. An illusory meeting with the wallpaper-incarcerated woman stirs and finally upsets the narrator's sanity. Still, the question of sanity / insanity (and thus the essence of the main event) is not yet entirely solved, for different expositors, especially those transferring the story to the screen, see the narrator's madness from various angles: Gothic, feminist, political, etc. The story has been adapted into several screen versions, viz. "The yellow wallpaper" directed by John Clive (1989), "Confinement" by John McCarty (2009), "The yellow wallpaper" by Logan Thomas (2012), "The yellow wallpaper" by Amandla Stenberg (2014), "The yellow wallpaper" by Kourosh Ahari (2016).

All these adaptations have been made possible due to intermediality - a phenomenon dealing with various ways of conveying content, for example, literary texts converted to other media. Medium here is a kind of representation (Wolf 2007: 36), a way of representing an event. The choice of representation may appear important for the story and its tellability, or the quality of being worth telling (Ryan \& Thon 2014: 25). Intermediality presupposes not only exceeding "the limits of 
media", but also variation in form and function of such transfers with reference to certain products - works of art that emerged in the process and their cultural and historical interrelations with the sources. Intermediality may be studied as a fundamental category not bound by disciplinary borders and as a sphere of analyzing certain intermedial products that appear as a result of reconfiguring original works in other media (Arvidson et al. 2007: 14-15; Clüver 2007: 32; Rajewsky 2005: 46-47). Full-length films or TV shows (TV serials), musical works (operas or musicals), comics, computer games (Ryan \& Thon 2014: 10) are typically recognized as media of adaptation, though fiction works (literary and cinematic) may be adapted into other fiction works within the same medium. Thus, a novel may interpret the main event of another novel, a film - the event of another film, etc. (Genette 1997: 239, 355-356, 573), for instance, the novel "Pride and prejudice, and zombies" by Seth Grahame-Smith adapts "Pride and prejudice" by Jane Austen, the film "The wolf man" (1941) adapts "The wolf man" (2010).

Intermediality is to be understood as a prerequisite for polymorphism (from Greek $\pi о \lambda v ́ \mu о р \varphi о \varsigma-$ diverse (Хориков \& Малев 1980: 640) - a conjectural quality of a certain narrative to be realized in the same medium or in different ones with or without great changes in the main event (either physical or mental) that makes that narrative identifiable. "The yellow wallpaper", for instance, may thus become a feature film, a dramatic stage play, an opera or a series of comics, but the woman behind the wallpaper pattern as well as the narrator capable of seeing her are the necessary entities to be rendered in each new screen or other version. Otherwise, the event of the original literary narrative will not be identified or recognized. This article treats polymorphism in the sense outlined above, and this correlates with its aim. So far, the quality of polymorphism is conjectural. The term per se has been introduced by the author and assayed in a few articles; it denotes something immanent to the main event that may be either realized in other media or not (Игина 
2017a: 129-137; Ihina 2015: 77-82). Therefore, the quality of polymorphism is latent and not obligatory. It is not exterior, i.e. suggested by the author, but interior, conditioned by the topicality, significance, popularity, and other features of the event. In this light, the opposition between intermediality and polymorphism is seen as transcendental vs immanent.

\section{Material and methods}

The aim of the article is to explain polymorphism and the polymorphous Gothic narrative over against intermediality, the latter being not immanent but transcendental when viewed with reference to transforming the event in the same medium or in different ones. Furthermore, to categorize Gothic narratives in different media, a classification based on the criterion of polymorphism is to be introduced. Narratives that belong to the Gothic and, to date, have been transferred into other media constitute the source of the material under study. The objectmatter of the research is polymorphism - a phenomenon constituting the immanent quality of Gothic narratives and making for their intra- or intermedial transference. The narratives based on the main event of the Gothic and characterized by polymorphism represent the subject-matter of the article.

The expected results concern determining the main event of Gothic narratives, revealing a new narrative quality realized together with eventfulness as one of the principal qualities recognized in narratology so far, and classifying polymorphous Gothic narratives. The methods applied are: the analysis of the event's entities, which is a method used in structural narratology; the Hegelian dialectical method for determining the relations between the entities and the event; the continuous sampling method for identifying Gothic narratives; the multicriteria classification based on decomposition and stratification. The attribute multicriteria denotes choosing narratives that meet three criteria - eventfulness, polymorphism, and 
reference to the Gothic tradition. Decomposition stipulates that narratives are to be classified only according to these criteria and exclude any random criterion that may acquire prominence in the process. Stratification presumes layering the qualities of polymorphous Gothic narratives, e.g., the authenticity of retranslation or the event's transformation (see Paragraph 3.2). The analysis of the event's entities presupposes setting the elements of the event aside from one another (for there are two of them in the Gothic event) and explaining their features of identification, namely those that make their rigid opposition possible. The Hegelian dialectical method is used to show the relations of the main Gothic topoi, especially in terms of their mutual subordination and interconnection within dialectic unities (the event includes the entity, the entity presupposes two opposed elements, etc.). The continuous sampling method serves to identify Gothic narratives among other types of narratives by searching for texts and films that meet the aforementioned criteria. The method of decomposition restricts the number of these criteria. Therefore, the criterion of violence (typical of slasher films, for example) is not taken into account though violence is often present in Gothic narratives as the element of their specific gloomy atmosphere (also known as the pall). Stratification helps to reveal the interconnected principles that underlie polymorphous Gothic narratives.

\subsection{Intermediality vs polymorphism}

The ambiguous treatment of intermediality springs from the fact that it presumes not only transference into other media, but also slight or significant transformations of the main events in the transferred works under the influence of new media. There is a distinction in applying the term intermediality to specify shifts of the event within the same medium or among different media. The shifts of the first type are known as interart relations, and the works related this way - as semiotic complexes, or intermedial artefacts. Semiotic complexes may concern transmedial phenomena and be realized as ways of organizing and transmitting information (such as, for example, 
narrativity) as well as ideas and variations of those ideas in literature, music, and applied arts (Wolf 2002: 15, 17). If intermediality is connected with modes of transforming the initial event in other media, it embodies the genetic conception presupposing the original and its remediation (Bolter \& Grusin 1999: 44-45). If some event is taken from its primary medium and interpreted in the secondary one, the transference mode is intermedial, alias intersemiotic transposition (Clüver 2007: 33; Rajewsky 2005: 51), extracompositional intermediality or transmodalization elsewise (Genette 1997: 237, 395; Wolf 2002: 18-21). Predominant examples are adaptations of novels into films (screen versions) or films into books (novelizations) though the intersemiotic character of these adaptations is only a formal aspect of transference. Any novel interpreted as a film is an obvious result of embodying its main event by cinematic means, still, that result becomes not only an extracompositional product, but also an intermedial artefact. The event with all its circumstances and entities is subject to changes on the screen (Clüver 2007: 33). Extracompositional intermediality is shown in the form of intermedial matrix (Fig. 1) where the original stands for the initial medium of a certain event and transponents indicate intersemiotic versions.

For example, Henry James's novella "The turn of the screw" was adapted as several films, an opera, two ballet performances, and a dramatic stage play. Thus, the literary text here is the primary medium (the original), and its transponents are an opera, a dramatic stage play, two ballet performances, and six film-adaptations. The screen versions are "The innocents" (1961), "The nightcomers" (1971), "The turn of the screw" (1992), "Presence of mind" (1999), "In a dark place" (2006), and "The turn of the screw" (2009). The opera "The turn of the screw" was composed by Bendjamin Britten, and the dramatic stage play "The turn of the screw" was adapted by Robert Lenkiewicz. Two ballet performances are known as "The turn of the 
screw" (1980) by Luigi Zaninelli and "The turn of the screw" (1999) by Will Tucket.

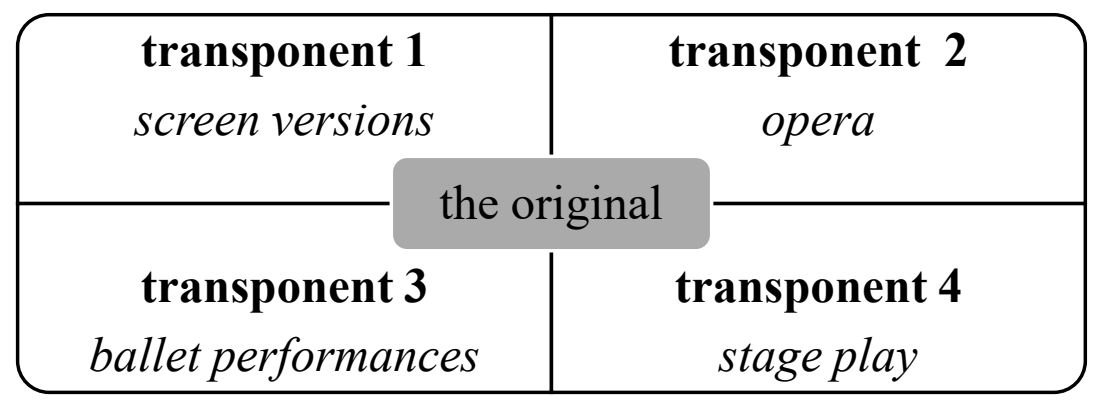

Figure 1. Intermedial matrix

Intracompositional intermediality is allocated within the composition, i.e. a film, an opera or a stage play are multimedial complexes (intermedial fusions) including the textual part, visual effects, and music. Texts in their turn may be accompanied by illustrations that reproduce events, and comics - by texts (Rajewsky 2005: 51). A libretto is always realized as an intermedial combination since it is initially planned within the complex (opera) (Wolf 2002: 22-23, 28-29). Intermedial reference - a variant of intracompositional intermediality - refers, accordingly, to other media (a systemic reference) or to other intermedial works (an individual reference) though the original medium is not changed (Rajewsky 2005: 53). Intermedial references may be implicit and explicit, the former somehow imitating other media or artefacts and the latter containing literal allusions or naming actual works. Imitations of the first kind stimulate associations that may be embodied as memory evocations (for example, ekphrasis) or as formal imitations when one medium takes the form of another (shape poetry, program music). Explicit intermedial reference is also known as intermedial thematization (Wolf 2002: 23-26). Thus, there are a lot of portraits of writers (Charles Baudelaire, Franz Kafka, Edgar Allan Poe, Mark Twain, Oscar Wilde) in the arthouse vampire film "Only lovers left alive" (2013), and the main female character, Eve (the name per se is a biblical allusion), is a 
bibliophile. She travels with trunks full of books from all times (for she is more than a thousand years old), and the names of Samuel Beckett, Miguel de Cervantes, and David Foster Wallace are among the authors. In another arthouse vampire film, "Addiction" by Abel Ferrara (1994), the main character (the first-person narrator) is a vampire-proselyte and - pluralistically - a postgraduate student who is working on her thesis in philosophy and never gets tired of quoting George Santayana, Friedrich Nietzsche, and Søren Kierkegaard. Together with her vampireaccomplices, she turns her defense into a blood-orgy where all prominent intellectuals are bitten and turned into vampires. Vampirism here is a metaphor of total misinterpretation of the cited philosophical trends and therefore of their vanity and futility leading to drowning the deceived humanity in blood. In the film by Neil Jordan "Byzantium" (2012), the male characters have the names alluding to John Polidori's and George Byron's characters - Ruthven and Darwell accordingly.

All types of intermediality often coexist in one work. A screen version is the result of transmodalization, but it is also a fusion (for it includes music) and reference, for it has allusions (Rajewsky 2005: 53). The films mentioned above ("Only lovers left alive", "Addiction", and "Byzantium") are fusions and references at once. Thus, the phenomenon of intermediality consists in multiple overlap of media in works of art and works of fiction and is a condition for intermedial artefacts to emerge.

Polymorphism differs from intermediality, for it is merely a particular/special case of the latter. The term denotes a quality of a concrete work, for example, a certain Gothic narrative to be realized in the same medium or in different ones. Such narratives as "The yellow wallpaper" or "The turn of the screw" are remediated, i.e. the medium's change is involved, but if a Gothic narrative is realized within the same medium, it also becomes polymorphous since the same event acquires interpretative features. Therefore, a polymorphous narrative is a story about some 
event that has already been realized as an intra- or intermedial artefact, i.e. within one medium or in many, and thus there is the original and its transponents (either intra- or intermedial).

"The turn of the screw" (the original medium is the novella by Henry James) was reinterpreted as an opera, several screen versions, and several ballets, i.e. the event, described in the original, was transformed to become the event of feature films and musical adaptations. It should be noted that the event in all adaptations has not undergone significant changes, and it is possible to identify all interpretations as the same narrative about Miles and Flora being corrupted by their late governess and her lover even posthumously. The main event here is the opposition between the known (the children - Flora and Miles and the narrator - the current nameless governess) and the unknown (the ghosts of Miss Jessel, i.e. the late governess, and her corrupt lover Peter Quint). "The turn of the screw" is thus a polymorphous narrative. In this feature, it differs from, for example, the novella "The wicked voice" by Vernon Lee. The confrontation between the real narrator telling about his adventures in Venice and the unknown represented by a mysterious ghostly voice capable of murdering people is described only in the literary text, the novella "The wicked voice". Though the novella is full of intracompositional intermediality, this feature is not connected with narrative polymorphism since polymorphism refers to interpreting a concrete original event. A polymorphous narrative is a synthetic construct created by writers, directors, scriptwriters, composers, illustrators, a reiterated reflection of seemingly the same object that meanwhile acquires characteristics ascribed to the ship of Theseus. The question with this ship is whether it remains the same object if all its components are removed, updated, substituted, etc. (Plutarch 2013: 20). 


\subsection{Specificities of the Gothic}

The Gothic combines dissimilar ideas of pseudomedievalism, romanticism, and Protestant providentialism. Romanticism and Protestantism are both motivated by destiny, intuitivism, and doom (Жаринов 2000: 21, 41; Birkhead 2008: 29-39; Botting 2005: 6). Therefore, it is logical that the Gothic relies on the irrational thesis, i.e. an illogical approach to narration (Менегальдо 2011: 483, 487, 493). Deliberately, they inspire anxiety and fear thus reflecting social ill-being in the most primitive, straightforward manner. The acute themes of the past centuries have turned out topical now. The renewed attractiveness is ascribed to some oppositions of the classical Gothic (Cavallaro 2002: 9; Edwards 2003: 110; Horner \& Zlosnik, 1998: 5, 32, 45; Karschay 2015: 31, 37, 51-53, 58, 63; Spooner 2006: 8; Wasson 2015: 101), such as:

1) the past vs the present (the past weighs on the present, the dead seizes the living);

2) a stable mind vs divided personalities;

3) norm vs abnormality (sickliness, morbidity, ugliness, mutilation, degeneration, hybridity, modified bodies);

4) civilization vs savagery;

5) enlightenment vs obscurantism;

6) morality vs licentiousness;

7) discipline vs disorder;

8) rational vs chimerical;

9) sacred vs profane;

10) natural vs supernatural;

11) literary and cinematic representations of confinement vs freedom.

The Gothic stems from a mixture of eastern religions as well as pre-Christian beliefs and heterogeneous forms of artwork reproducing archetypal features of medieval ballads, folklore tales, and Renaissance literature (Botting 2005: 4-10). Besides, the 
idea of confrontation between the known and the unknown could not be possible without Protestantism (see the beginning of Paragraph 2.2). The world of light, chastity, and spiritual purity of the Virgin was inconceivable for a Protestant without its opposite - the world of the God's monkey, the devil (Diabolus est simia Dei). That other - perverted - world was believed to be full of witches, kobolds, wizards, werewolves, etc. who easily took the shape of people and were experts at plotting perfidious schemes against the innocent. Life was a constant struggle with his sable Majesty. A person who was every minute at the verge of the precipice was horrified. Witches' covens, satanic masses or black magic were true in his world. He could not be certain whether his friend had not had a pact with the devil yet and a girl who looked respectable had not yet become the devil's mistress since the woman (as a generic character) was believed to be the path into the world of people for the devil. Horned and clawed images of the hell were already common for the medieval mysteries, and the imagination of Gothic art is full of them (Стефанов 2011: 22; Шпенглер 1998: 299-302). The plots of the Gothic are systematically associated with crossing the borders of the world seen as real, habitual, and clear (Botting 2005: 2, 4-5; Costantini 2003: 155-156; Smith 2007: 94-101). However, the term real in this context is conventional and does not concern reality as a philosophical category born in the era of Enlightenment. It is not at issue in the Gothic, at least not from the perspective of the involved parts - Gothic entities. The part of the unknown is played by the devildom of various sorts (and not only of European origin), and the part of the known - by human characters in their usual, habitual realm, i.e. a narrow domain perceived by all of them in more or less similar ways. Everything beyond their domain is believed to be a different world, though connected with theirs in some mystical incomprehensible way. These two domains of the known and the unknown are the realms of being (Головин 2003: 465) in the Gothic, and the border between them is an interstitial layer of vague dreams where everything is partly known, partly incredible (Дугин 2009a: 5). Sometimes the 
interstitial layer is described in terms of the Gothic séance - a seemingly physical experience of the paranormal and communicating spirits, a visionary space which is not totally unreal, but is between the two (Taylor 2015: 163, 166).

\subsubsection{The Gothic canon in literature}

The ideas of the Gothic that make up its canon are seen in the light of traditionalism, for they do not require special explanations and are intuitively understandable in terms of separating the real from the supernatural. The classical literary Gothic is dramatically antagonized to positivistic worldview and consists of recognizable stylistic and plot fundamentals known as the castle chronotope (Бахтин 2012: 285; Bakhtin 1981: 84, 245-246). Besides ruinous family castles, the backdrop includes cursed and forlorn houses, ghost-houses that are anomalous in themselves (but not due to a curse), decadent palaces (sometimes oriental), charnels, cemeteries, monasteries, evil places where something creepy has happened, etc. The ghosts of split and unsteady identities haunt the narrative as bats haunt the houses (Жаринов 2016: 53; Brien 2015: 149). The ominous and depressed atmosphere complements the castle chronotope, and the event is happening in the dark, at night, in a thunderstorm. Fear and paranoia, wicked desires, hallucinations, and revelations haunt wretched and vacillating, never happy characters. Daemonic, often immortal, antagonists crave for seducing Gothic heroines (aristocratic maidens full of morals). Femmes fatales are a curse of Frankenstein- or Faust-like scholars, otherwise absorbed by the occult knowledge of forbidden grimoires (such as Necronomicon or the Yellow Book) and clandestine brotherhoods. Insane love, incest, handicapped anomalous children, and various obsessions are the lesser evils of these outsiders. The real trouble comes with the monsters: hungry ghouls, werewolves, vampires, gargoyles (or horrific effigies of that kind) (Жаринов 2000: 177, 226-227; Cavallaro 2002: 30-60, 75-85, 179-199; Crawford 2015: 39; Demata 2003: 13-35; Georgieva 2013: 51; Milbank 1992: 26; Peaty 2015: 54-56; Punter 
2001: 11, 13, 15; Punter \& Byron 2004: 259-298; Roberts 1990: 9-18, 37, 127-131; Snodgrass 2005a: 120-121; Snodgrass 2005b: 156-157). The most eminent pioneers of the Gothic are William Beckford, Edward Bulwer-Lytton, Montague Rhodes James, Mathew Lewis, Arthur Machen, Charles Maturin, Ann Radcliffe, Clara Reeve, Edgar Allan Poe, Mary Shelley, Joseph Sheridan Le Fanu, and Bram Stoker.

Several criteria are important for classifying the Gothic. For example, they are connected with cultural and historical features of the periods when the respective work was written. Therefore, Victorian, imperial, postcolonial, decadent, modernist, postmodern, and romantic Gothic are discerned (Armitt 2006: 78-93; Brantlinger 2006: 153-168; Davis 2006: vii; Fitzgerald 2006: 48-62; Lloyd-Smith 2006: 136-153; Marsh-Russel 2006: 14-15; Punter \& Byron 2004: 26-32, 39-59; Smith 2007: 10; Wisker 2006: 168-182; Wolfreys 2006: 62-78). National and ethnic peculiarities of the authors or places of their living make up, for example, English, American, African-American, Canadian, Irish, Australian types of the Gothic (Gelder \& Weaver 2007: 1-7; Hansen 2009: 59, 87; Savoy 1998: 3-20; Shanahan 2014: 74-94; Smith 2007: 33-41, 61-75; Wester 2012: 35-67). The author's gender, accordingly, splits the Gothic into the male and female varieties (Horner \& Zlosnik 2006: 107-121; Williams 1995: 108-115, 135-141; Wisker 2016: 63-91). Feminist Gothic is based on the philosophical trend of feminism (Perry \& Sederholm 2009: 19-39). Gothic novels and Gothic stories differ according to large or small literary forms. Plot specificities typify the classical Gothic novel of mystery and terror, ghost-story, neogothic novel, horror novel, zombie-story, strange tale, uncanny story, weird tale, magic realism, dark fantasy, presque vu (stories about transpersonal experience), tale of unease (Бавина 2011: 13; Жаринов 2000: 198, 320-321; Липинская 2011: 9-10; Чамеев 2009: 5; Botting 2005: 16, 82; Davis 2000: ix-xiv). 
The first Gothic novel, "The castle of Otranto" by Horace Walpole, was published in 1764 to be later named a "new species of romance" (romance vs novel) due to the specific and recognizable ballade background (Скотт 1992: 181, 188; Birkhead 2008: 29-39; Ledoux 2013: 24; Watt 2004: 12-14): knights' armor, family feudal curses, and beautiful ladies. Narrative composition suggested by Horace Walpole reproduces a game with an ancient manuscript found by some descendant of a noble ancestor and connected, accordingly, with dark family secrets. The game is based on numerous embedded narratives that help to solve the main mystery, form a closed-circuit cycle and invite the reader into it (Жаринов 2000: 169; Clayton 2017: 5-9; McEvoy 2013: 481). Playing games and simultaneously being absorbed in dismal seriousness of family enigmas, the reader of the Gothic narrative gets involved into the absurd tragedy where the rational has roots in the irrational (Заломкина 2011: 10-11). The Gothic novel has developed two trends: 1) with a rational final explanation of seemingly irrational things and 2) interpreted from a mystical and metaphysical stance (Todorov 1975: 44-45).

\subsubsection{Transformations of the Gothic canon in literature and film}

Horror and neogothic novels (of the $20^{\text {th }}$ and the $21^{\text {st }}$ centuries), both being literary descendants of the Gothic novel, reconsider the Gothic canon of the $18^{\text {th }}$ century and are often adapted as screen versions, especially as horror films. The horror novel concentrates on the details of violence. The neogothic novel is a novel of secrets and enigmas, therefore the event is practically always conditioned by the unfathomable metaphysical evil (Snodgrass 2005c: 306) though the protagonist, contrary to his predecessors, always prefers to explain his metaphysical esoteric experience rationally. If he fails, he mythologizes it, tries to perceive it as a dream, illusion, delirium, alcoholic or drug inebriation, i.e. the altered state of consciousness that he considers necessary for interpreting unusual information (Заломкина 2011: 374; Полторацкая 1992: 6-9). The focus of the horrible often 
shifts to the psychological sphere; therefore, much attention (especially in the modernist type of the Gothic) is paid to deviations and aberrations (Botting 2005: 103-105). Characters try to look inside their souls and "conquer the fear of Caliban" (Beville 2009: 62) who, according to Oscar Wilde, saw himself in the mirror. Their focus lies in choosing between the good and the bad in their own hearts and in determining their true selves in the fragmentary psyche. Such a state is known as the ontological doubt (Beville 2009: 43-48) caused by the inability to discern the truth in the world.

If modernist themes in the Gothic are those of the fragmented or split state of mind and the choice between the good and the bad in search of the real self, postmodernism supplants morality by moral relativism (McHale 1987: 141). The world without morality brings danger, for it is deprived of priorities and causes the greatest, cosmic fear of the unknown by its aprioric incognizability (Lovecraft 1973: 17, 55, 82). This fear is eclectic and has two complementary images - terror and horror (Botting 2005: 46-51; Cavallaro 2002: xii; Radcliffe 2004: 47). The former "expands the soul", the latter "contracts, freezes" feelings. The difference between them concerns "the respect for evil", which evokes curiosity and delight together with fear. A person might find pleasure in expanding the limits of imagination, for the unknown frightens more than the known and demands more psychic unease and tension (Summers 1964: 49). Terror refers to the classical castle chronotope and "the outer evil" of alien monsters that are as dangerous as wild animals. Scenes of violence, including cruel crimes, are always seen as monstrous or bestial (Kristeva 1982: 13). A most terrifying image is that of some living being lurking in the dark to cause pain. The fear acquires metaphysical forms of some dangerous conscious existence that must be avoided (Inverso 1990: 120). Horror reproduces grotesque, repulsive, cruel "inner evil", the latter usually seen as the invisible eternal conflict between the Apollonian and Dionysian in a person because psychic mutations are not always 
noticeable behind "the apollonian façade of normality" (King 1983: 63, 76, 396). The characters of such modern Gothic authors as Peter Ackroyd, Clive Barker, Robert Bloch, Neil Gaiman, William Hjortsberg, Thomas Ligotti, Whitley Strieber, etc. fight the inner evil that expands via the reader beyond the measures of narratives, and the fear is recognized as a single expression of some reality behind it. The reader under these circumstances experiences suspense (from Lat. suspendo - hang up).

Suspense has not yet acquired a concerted explanation, but it is always connected with anxiety and psychological discomfort as well as with pleasure from the absence of immediate danger. Such mixed feelings are caused by the attitude to the Gothic as to "dark narratives" and "textual constellations of violent desecrations of common sense and logic", "a dark brew of fear, pleasure, nightmare, and comedy" (Cavallaro 2002: xvii, 2). The question about the end of the narrative is formulated beforehand and has two alternatives - a possible happy or unhappy end or a problematic happy or unhappy end. It unites pain and pleasure in the fictional world beyond the measures of contrast, and fear - the strongest emotion - makes the reader choose between the alternatives from an imaginary distance, which turns danger into delight (Burke 1998: 31, 36-37; Carroll 1990: 137-138). Balancing on the verge of contrasting reactions is not a healthy feeling and may be even considered a form of pathology, a specific Gothic frisson, logical unease, the binomial of anxiety and pleasure caused by playing with fictitious dangers (Barthes \& Duisit 1975: 267-268; Davis 2006: vii). The frisson arises, for the narrative should have a logical end, but simultaneously it implicates "the disturbed presence" (Головин 2003: 333) connected with intuitive angsts up to the moment when one of the alternatives comes true. In other words, suspense in the Gothic is a sense of foreboding, of anticipating something that has not yet happened and waiting for the author's explanations that may or may not be given. 
The film Gothic mostly uses the themes of horror novels though the popularity of such classical Gothic narratives as "Dracula" or "Frankenstein" have also resulted in a number of adaptations. In general, the film Gothic has several subclasses (Cherry 2009: 5-6):

1) Gothic movies (adaptations of the Gothic novels written by the pioneers of the tradition);

2) occult films ("Rosemary's baby", "The exorcist");

3) psychological horror films ("Carrie", "Hannibal");

4) splatter and gore body horror ("Resident evil", "Cannibal holocaust");

5) films about monsters ("Aliens", "Godzilla");

6) slashers (from slasher - a big knife ("Halloween", "Scream"));

7) explicitly violent films, exploitation cinema, grindhouse ("Hostel", "Saw");

8) dreadpunk (refers to a subgenre of modern fiction that takes its cues from the $19^{\text {th }}$ century Gothic; dreadpunk stories unfold in Victorian England or in a world resembling that time (Romano, s.a.), e.g., "The extraordinary adventures of Adèle Blanc-Sec", "Salem's lot", "Edward Scissorhands".

These subclasses reflect different nuances and genre aspects of the event, such as those connected with classical plots of the Gothic (in Gothic movies or occult films) or with their modifications concerning either psychological torments of characters (treated as some internal evil in psychological horror films or dreadpunk films) or external or alien, monstrous intrusions into the characters' lives. The intruders may inflict physical or other kind of pain on them threatening their mental or physical comfort (in splatter and gore body horror, monster films, slashers, violent films).

\section{The main event of the Gothic}

The Gothic - according to the sources mentioned in the previous paragraphs - is a worldview model fixed in the artistic fictional form that generalizes the idea about 
human inability of self-identification in the perceived world. Impossibility of selfidentification gives rise to doubts in trustworthiness and cognoscibility of that world, to a stable belief in one's own defenselessness and vulnerability before unknown frightful forces. The known world, or basic reality (Головин 2003: 90) confronts the powers of the unknown, and the culmination of their opposition within the Gothic lies in the event of collision that embodies the existence of both parties and their realms of being (Ihina 2017: 90). Accordingly, it is the event of co-being, cohabitation, co-presence. The absence of co-being excludes a work of literary or other art from the Gothic, and though the Gothic has been the source of many fantastic genres, it is always reflected the traditional, but not scientific worldview. For example, the Gothic event of co-being differs from the main event in science fiction (Заломкина 2011: 98; MacArthur 2015: 3). In contrast to alien civilizations, the Gothic unknown is construed as occult and mystical. It refers to esoteric and mythological knowledge, which is alternative to positivism. Thus, the term "reality", as it has been mentioned, is applicable to the Gothic basic realm of being only conventionally, to denote the domain of everyday habitation as some common familiar denominator. Reality (from Latin res - thing) is a term of positivistic science that postulates no being and thus cancels either the immovable engine, the prime mover of manifestationalism or the creator of creationism. Positivistic reality is immanent to itself and accidental (Дугин 2009b: 232), while everything in the Gothic is predestined and doomed.

The event of confrontation is the so-called prime mover that does not move itself but moves the movable (Аристотель 2002: 143; Aristotle 1998: 372). It is the point of attraction for all the entities of a Gothic narrative (active characters as well as natural / known and supernatural / unknown entities that surround them). It makes the mythological fictional world of the Gothic manifestational (Lat. manifestare expose). Manifestationism, or manifestational worldview, is based on the holistic 
order, and thus the driving impetus of that world (including all four Aristotelian causes: material, formal, moving (efficient), and final) and the world itself exist in holistic integrity and are cyclically realized through one another.

Manifestationalism is a prescientific, traditionalistic way of thinking; it is based on seeing chronological causality not outside a phenomenon, but inside it, i.e. the event is connected with all entities not diachronically (as a result), but synchronically (as a part of entities). Cyclic manifestationalism represents the traditional world with all its entities as the revealed, exposed truth to which the totality of entities refers as its otherness, its other side, bound to the event of co-being. The principle of such mutual cyclicality is described as creatio ex deo, i.e. creating out of the deity (Генон 2008: 15; Дугин 2002: 72-73). Different devilish entities of Christendom, especially in its Protestant dimension, that embody the part of the unknown could be mistaken for the beings of creationism, another traditionalistic paradigm that segregates Abrahamic from non-Abrahamic beliefs and to which Christianity belongs (Дугин 2009b: 216-228). However, in the Gothic the devil and his mates are conventional figures used to tell the unknown from the known. In the Gothic, the devil is not Princeps Omnium, but one among many other evil forces including those from different cultures, such as Chinese and Japanese ghouls and fiends or Indian and Native American paranormal guests, etc. (Blackwood 2013; Hearn 2006; Kipling 2006).

In terms of Hegel's dialectics, the knowledge emerges as the final result of three interconnected stages - the rational, the dialectical, and the speculative, also known as thesis - antithesis - synthesis (Гегель 1937: 22-25, 33, 35-37; Hegel 2010: 35, 71$74,80,588-589,509,527,606-608)$. The following key statements may be singled out of the generalized Gothic specificities:

1. The known rigidly confronts the unknown - the thesis. 
2. Every element of the opposition is split, i.e. it has additional inner oppositions (I and non-I within the same fragmentary consciousness) - the antithesis.

3. The known and the unknown merge in the event of co-being and become interdependent - synthesis.

Thus, the first item reflects the principle of dividing into antinomies, characteristic of rational thinking, the second outlines the inner dialectics of both opposemes, and the third shows that the initially contrasted elements (thesis and antithesis) synthesize into something new, important for understanding each of them. The known in this opposition is something bewitched, intrigued, and frightened by the unknown, and the unknown embodies the ontological doubt.

To recapitulate reflections about the Gothic, certain conclusions should be made. The known and the unknown are the key Gothic entities antagonising each other, and their confrontation is the event of co-being. The entities catalyze the event and are, therefore, its cause though the event is also realized in the entities themselves, thus becoming the result of catalysis. Still, this closed circle is not a vicious one since it may be clarified by means of the same Hegel's method. The entities "enter" the event separately (opposed to each other). Then they start (as the event's elements) interacting with the event dialectically and mark their stance as a state different from that of the event, where the latter is the hidden truth of their otherness, the source of their confrontation. They both influence the event's development depending on their inner qualities.

The entities and the event, connected by the mystery of each other's otherness, are thus the three topoi important for understanding the Gothic: 1) the event of co-being; 2) the Gothic entity; 3) the entity's will to mystery as the revelation of its own source (Игина 2017b: 92-98). 
The entities strive for the mystery of their mutual recognition when they get to know each other, and this impulse initiates and directs their actions like the fundamental impulse of will, which has had a variety of interpretations throughout history. Nondetermination and spontaneity are its major features that tend to turn into a constant inexplicable need, an urge towards something, for instance, life (Schopenhauer 2010), power (Nietzsche 1968), or knowledge (Foucault 1978). Likewise, the will in one of its manifestations (the will to mystery) is a topos of the Gothic. Something that is kept from others, innermost, hidden, and secret presumes those who are the chosen few and those who are not. The desire to get into the circle of the select few, to find a way to something secret and forbidden is inseparable from the idea of the unknown.

The term topos denotes an integrated notion of the Aristotelian probable argument, a piece of ready knowledge accepted as verisimilar and credible (Аристотель 1978: 347-553; 2000: 5-149), an indication of something archetypal, a traditional repetitive pattern in art and literature, for example, love, old age, confrontation of nature and man, etc. (Curtius 1953: 80-83). The event of co-being (confrontation of the known and unknown) manifests itself in becoming the generic topos with regard to separate entities and shifts the rational to the dialectical level. Interrelation of the event and entity makes up the generic topos with regard to the event and the entity as specific topoi and transfers the dialectical to the speculative level. For example, Hamlet - a Gothic entity on the part of the known - interacts with his father's ghost a Gothic entity on the part of the unknown. This event of co-being causes such drastic changes in the prince's mind that all further incidents and actions would have hardly happened if it had not been for the talk with the ghost. The prince's knowledge coming from a supernatural source becomes the force that ultimately transforms the event of co-being into the event of Hamlet's death, i.e. confronting the death as one more entity of the unknown. 
The Gothic entity, the event of co-being, the will to mystery and, accordingly, their interrelation at dialectical and speculative levels, make up the topoi of the Gothic by embodying the Gothic myth in literature and film.

All works of the Gothic are bound by the same topoi. The fateful event of co-being lies in unfolding the joint Gothic entity (the known and the unknown) in time, and this immanent temporal dimension is another piece of evidence for treating the Gothic as narrative.

\subsection{The main event of the Gothic through the prism of polymorphism}

The main event of the Gothic, co-being of the known and the unknown described above, is realized in polymorphous narratives identically or with changes that other writers, scriptwriters and directors make while interpreting original sources. Polymorphism presupposes the narrative's depth and scope.

The depth of polymorphism is a measure of homomedial shift, i.e. a degree to which the same Gothic narrative is interpreted in the same medium.

1. In this connection, shared universes should be mentioned as an example, where a fictional world created by one author is elaborated by additional episodes, details, and characters in the works of other writers. August Derleth and Robert Howard have developed and elaborated the fictional world of Howard Philips Lovecraft in their novels.

2. Several screen versions (with reference to each other but not to its literary source) are homomedial shifts as well. Both films "The innocents" (1961) and "In a dark place" (2006) are based on "The turn of the screw" by Henry James.

3. A film and a series (TV show) that have the same source, for example, the fulllength film "Sleepy hollow" (1999) and the TV show "Sleepy hollow" (2014) may 
be analyzed according to the depth of polymorphism where the Gothic narrative unfolds around the same event first described by Washington Irving.

4. Homomedial shifts are characteristic of such a form of creative activity as liminal literature, also known as crossover in films. In those cases when other media are involved, the liminal works become, accordingly, heteromedial interpretations. The term crossover (genre blending, genre crossover, hybrid fiction, literary mixing, mash-up, interstitial (liminal) fiction, slipstream, the new weird, post-genre fantastic) denotes narratives created by mixing genres, events and characters from different sources, e.g., "Pride and prejudice and zombies" by Seth Grahame-Smith. In addition, it refers to literary or cinema works meant for children, but popular among the adults (Luckhurst 2015: 87; McArdle 2014: vii), such as books about Harry Potter.

The scope of polymorphism is a measure of heteromedial interpretation of a certain narrative, for example, "The turn of the screw" as a literary text, film, opera, etc. Heteromedial interpretation of several Gothic literary narratives is the modern series "Penny dreadful" (2014-2016) where the following characters are involved:

1) Dr. Frankenstein and his monster (Mary Shelley's characters);

2) Dr. Jekyll (the protagonist of the Gothic novella "Strange case of Dr. Jekyll and Mr. Hyde" by Robert Luis Stevenson);

3) Allan Quatermain (Henry Rider Haggard's character from "King Solomon's mines");

4) Dracula (the character created by B. Stoker);

5) Lawrence Talbot (the character of the film "The wolf man" and its sequels).

The depth and scope are indicated in units (a unit of depth, a unit of scope). The scope index of such a polymorphous narrative as "Angel heart / Falling angel" is 2 (the novel by William Hjortsberg and the film by Alan Parker), "The turn of the 
screw" - 4 (the novella, the screen version, the opera, the ballet performance). The depth index of "Angel heart / Falling angel" is 1 (one screen version), and that of the Lovecraft's novella "The Dunwich horror" - 2 (two screen versions of the same name $(1970 ; 2009))$.

\subsection{Classification criteria of polymorphous Gothic narratives}

Since any Gothic narrative reproduces a literary, cinema or another work in varying degrees of authenticity, the main object of comprehension for an interpreter is the event retranslated in other media either with no modifications (but for the change of the medium) or with transformations influencing the event and thus the whole narrative. The ways of realizing the event in the polymorphous Gothic narrative may be identified as follows:

I. An authentic retranslation takes place when the original event is reproduced without significant changes, for example, in a screen version. This type may be:

1) detailed, where all characters and details are kept, e.g., the film "Dracula" (1931); 2) reduced, e.g., the film "The ninth gate" (1999) based on the novel "The club Dumas" by Arturo Pérez-Reverte; the film focuses only on the Gothic plotline, which, accordingly, concerns the devil's intrusion into the protagonist's life.

II. A modified retranslation takes place when the original event undergoes some changes caused by its interpreters:

1) according to the event's transformation, i.e. the outer entourage of the event is modified - time and place are changed or some characters are added, e.g.:

a) in the film "Dorian" (2004) the event is displaced to the end of the $20^{\text {th }}$ century;

b) in the film "Dorian Gray" (2009) additional characters are present;

c) in the screen version of the novel "Falling angel" the protagonist carries on his inquiry not in New York, but in New Orleans, and not in 1959, but in 1955;

2) according to the event's transmutation, i.e. with significant changes of the event's content, its essence, e.g.: 
a) the story "The worthy inmate of the will of the Lady Ligeia" by Thomas Ligotti modifies the original idea expressed in Edgar Allan Poe's "Ligeia" and represents the narrator not as a necromancer reviving the first wife in the body of the second, but as an object transformed by somebody else's will;

b) the Gothic fairytale "Snow, glass, apples" by Neil Gaiman reinterprets the story about Snow White who proves to be the embodied evil and her stepmother - a victim.

The main event of the Gothic is enriched by details in other media, and these details become a necessary condition for modern interpretations of classical Gothic novels as well as new works. Nowadays such novels as "Dracula" are still being adapted for the screen (one of the newest screen versions is the series of the same name (2013-2014), but modern works exploiting the same topoi do not concede to them. Various modernized draculas as modified Gothic entities are closer to ethical and aesthetic standards of the $21^{\text {st }}$ century, e.g., "Twilight" (2008-2012), "Vampire diaries" (2009-2016), "True blood" (2008-2014), "Blood ties" (2007), "Blade" (2002-2004). It should be noted here that the modern way of representing such Gothic monsters as vampires or werewolves differs greatly from the Gothic canon. The will to mystery becomes a marginal topos since it is hardly possible to perceive an entity who gets up every morning to go to high school with human teenagers ("Twilight", "Vampire diaries") as something unknown and supernatural. In these narratives, an immortal vampire whose cultural experience is supposed to have absorbed centuries of personal development can easily fall in love with an eighteenyear-old girl. However, it would be highly problematic if the Gothic mystery were involved. Mina Murray-Harker in the classical "Dracula" is rather a symbol of living memory than a living woman, a manifestational enigma for Dracula to solve. In "Twilight", Bella Swan is a girl whose purely human qualities appeared attractive for her seemingly supernatural boyfriend, and this fact makes the event not Gothic, but melodramatic. 
Types of polymorphous Gothic narratives may be classified regarding the mode of retranslation that follows the pattern "the original $\rightarrow$ a transponent":

1) a literary text $\rightarrow$ a screen version (a full-length film and a series), i.e. realization of the Gothic narrative on the screen, e.g., "The turn of the screw", "Sleepy hollow", "Angel heart", "Dracula";

2) a literary text $\rightarrow$ a musical adaptation, e.g.:

a) the opera "The turn of the screw" (by Benjamin Britten);

b) the opera "Vampyr" (by Heinrich Marschner) based on the story by John Polidori;

c) the musical "Sweeney Todd: The demon barber of Fleet Street" (the adaptation of Stephen Sondheim and Hugh Wheeler) based on the story "The string of pearls" written by James Malcolm Rymer and Thomas Peckett Prest and later directed by Tim Burton;

3) a graphic novel (comics) $\rightarrow$ a screen version, e.g., the film "The crow" (1994) and its sequels (based on the comics of the same name by James O'Barr); 4) a graphic novel $\rightarrow$ a musical adaptation, e.g., the musical "The Addams family" based on the comics created by C. Addams (music and libretto by Andrew Lippa); 5) a crossover in literature and film, e.g., the aforementioned series "Penny dreadful" or the film "The league of extraordinary gentlemen" (2003), which is also a free screen version, i.e. a modified retranslation according to transmutation based on the comics of the same name by Alan Moore and Kevin O'Neill;

6) an original film $\rightarrow$ a novelization, i.e. a product opposite to screen version, e.g.:

a) several literary adaptations of the series "Supernatural": "The unholy cause" by Joe Schreiber, "Witch's canyon" by Jeff Mariotte, "Nevermore" by Keith DeCandido;

b) the novel "Crimson peak" by Nancy Holder (based on the film of the same name (2015) directed by Guillermo del Toro and written by Guillermo del Toro and Mathew Robbins); 
7) an original film $\rightarrow$ a remake or series, e.g., "The wolf man" (1941) and "The wolfman" (2010), "The omen" (1976), its remake of the same name (2006) and the series "Damien" (2016);

8) modified retranslation ("Dracula 2000", "Dracula 3000");

9) shared universes and fan-literature based on the themes and motifs of popular novels, films, TV shows, e.g.:

a) the novella "A study in emerald" by Neil Gaiman, which combines fictional worlds created by Arthur Conan Doyle and Howard Philips Lovecraft (Queen Victoria in this combination is a supernatural cephalopod and Sherlock Holmes acts as his rival Moriarty;

b) Robert McCammon's novel "The Ushers' passing", which suggests a pseudoscientific explanation of the genetic illness described by Edgar Allan Poe in "The fall of the house of Usher" (the modern Ushers have to eat human flesh to ease the symptoms);

c) the film "Hemoglobin", also known as "Bleeders" (1997), which combines the motifs of "The fall of the house of Usher" as well as Howard Philips Lovecraft's "The lurking fear" and gives one more "genetic" reason for Ushers' malady - the results of incest.

In shared universes, the original event may be reconsidered so significantly that it acquires features of a different story. Therefore, it is hardly possible to correlate the malady haunting the innocent family in Edgar Allan Poe's story as the same illness caused by moral vices of the family from shared universes. The maladies in "The Ushers' passing" and "Hemoglobin" are the results of supernatural retribution, for physiological addiction to human flesh or incestuous mutations are caused by the Ushers' inhuman, monstrous behavior. The new Ushers are different Ushers and they frighten in a different way. Any sort of repulsion is natural for the Gothic (since nearly always disgust is accompanied by horror), but this horror is not as aesthetic 
as in the original. The new horror is a body horror (in terms of Brigid Cherry cited in Paragraph 2.2.2), and it has nothing to do with the classical Gothic.

\section{Conclusions}

The article discerns the terms intermediality and polymorphism (the second being a certain specific instance of the former) regarding their relation to the main event of the Gothic narrative. Intermediality is a precondition for polymorphism. The polymorphous Gothic narrative is not a literary narrative text or a feature film that narrates a story, but both at once, and the interconnection of media in their synergy is a way of expressing one and the same event.

Intermediality is a phenomenon dealing with ways of conveying literary, cinematic or other narratives to other media, and medium is a way of representing the event. Intermediality is studied as a sphere of analyzing certain intermedial products that resulted from reconfiguring original works, such as novels, movies, musical works, comics, or computer games, in other media. However, fiction works may be adapted into other fiction works within the same medium.

The event is a fundamental narratological category, and stating something as the event in a narrative becomes a subjective research procedure, for it is always based on biased reading or watching, and the choice of something (in a narrative) as being important or not is made due to some preliminary premise. For the Gothic narrative, this kind of premise is restricted by the obligatory presence of recognizable entities confronting each other, and to confront each other is their purpose. A head-on collision between the known and the unknown (the latter being embodied by supernatural, paranormal entities and the former - by usual, average people, phenomena, or things) underlies that purpose. Thus, the event is something that relates to the purpose, everything else is excessive. In other words, the event is 
concrete and has recognizable details that may be identified in other, non-original media representing the event by literary, cinematic, musical, and other means.

The polymorphous Gothic narrative is a multiple synthetic construct conceived and created by writers, scriptwriters, directors, composers, choreographers, etc. on the base of a certain literary or other work that tells about the event of co-being and is realized as an intermedial artefact in two or more media or as a reinterpretation within the same medium (an intramedial artefact). Polymorphism is a quality of the Gothic narrative to be reinterpreted in the same or several different media, and thus a narrative already adapted in the same or another medium is polymorphous. Thus, a certain polymorphous narrative may take several forms of polymorphism: it may be intermedial, intramedial, or intra-intermedial, depending on the number and types of media involved in polymorphous transformations of the event, and intermediality makes up, accordingly, only one facet of this construct.

The quality of polymorphism (the way it is seen in the article) relies on two criteria revealing its inter- and intramedial aspects: the depth of polymorphism is a measure of homomedial shift that a certain Gothic narrative makes within the same medium (e.g., the event of a film is reconsidered in another film); the scope is a measure of heteromedial interpretation of a certain narrative, i.e. when a novel is adapted as a film. Furthermore, the event of co-being that makes a Gothic narrative out of any other narrative may be realized in another medium as an authentic or a modified retranslation. The first one may be detailed and reduced, the second one-modified according to the event's transformation or transmutation. Transformation deals with formal superficial modifications of the original event, transmutation is characterized by significant changes. 
The classification of polymorphous Gothic narratives suggested in the article relies upon the mode of retranslation based on the pattern "the original $\rightarrow$ a transponent", where the original is the initial work further reinterpreted in the same or other media. Transponents, accordingly, are the final, ready products of reinterpretation (novelizations, screen versions, operas, comics, etc.). All adaptations make up the matrix of a certain polymorphous Gothic narrative, i.e. the narrative based on the same event. The term matrix is experimentally used in the article to refer both to the existing arrangement of adaptations (the current skeleton of transponents with the original as its head) and to the context (cultural, historical, or social) where the arrangement is recognized as a certain matrix. Any new transponent changes the context since the arrangement is changed.

In further research, the classification may be expanded with reference to different media and their combinations as well as to narratives of another, not Gothic type.

\section{References}

Aristotle (1978). Categories. Works in four volumes. Moscow: Mysl'. V. II. I Aristotel'. Kategorii. Sochineniya v chetyryokh tomakh. Moskva: Mysl'. T. II. I Аристотель. Категории. Сочинения в четырех томах. Москва: Мысль. Т. II. Aristotle (1998). Metaphysics. London: Penguin Books.

Aristotle (2002). Metaphysics. Translations. Commentaries. Interpretations. Saint Petersburg: Aletejya. / Aristotel'. Metafizika. Perevody. Kommentarii. Tolkovaniya. Sankt-Peterburg: Aletejya. / Аристотель. Метафизика. Переводьл. Комментарии. Толкования. Санкт-Петербург: Алетейя.

Aristotle (2000). Rhetoric. Moscow: Labirint. / Aristotel'. Ritorika. Moskva: Labirint. / Аристотель. Риторика. Москва: Лабиринт.

Armitt, L. (2006). Postmodern Gothic. In Teaching the Gothic. Powell, A. \& Smith, A. (eds.). New York: Palgrave Macmillan, p. 78-93. 
Arvidson, J., Askander, M., Bruhn, J. et al. (2007). Foreword. In Changing borders: Contemporary positions in intermediality, 1, p. 13-19.

Bakhtin, M.M. (1981). Forms of time and chronotope in the novel. In The dialogic imagination. Four essays. Austin: University of Texas Press, p. 84-259.

Bakhtin, M.M. (2012). Towards "the novel of education". Collection of works. Moscow: Yazyki slavianskoj kul'tury. Vol. III. / Bakhtin M.M. K "romanu vospitaniya". Sobraniye sochinenij. Moskva: Yazyki slavianskoj kul'tury. T. III. / Бахтин М.М. K "роману воспитания". Собрание сочинений. Москва: Языки славянской культуры. Том III.

Barthes, R. \& Duisit, L. (1975). An introduction to the structural analysis of narrative. In New literary history, 6 (2), p. 237-272.

Bavina, N. (2011). Facing the dark precipice. In Necronomicon. Kryukov, V. (ed.). Moscow: Enigma, p. 7-20. / Bavina N. Litsom k litsu pred propastiyu tyomnoj. In Nekronomikon. Kryukov V. (red.). Moskva: Enigma, s. 7-20. / Бавина Н. Лицом к лицу пред пропастию темной. In Некрономикон. Крюков В. (ред.). Москва: Энигма, с. 7-20.

Beville, M. (2009). Gothic-postmodernism. Voicing the terrors of postmodernity. Amsterdam: Rodopi.

Birkhead, E. (2008). The tale of terror. Charleston: BiblioBazaar, LLC.

Blackwood, A. (2013). Best ghost stories of Algernon Blackwood. North Chelmsford: Courier Corporation.

Bolter, J.D. \& Grusin, R. (1999). Remediation: Understanding new media. Cambridge: MIT Press.

Botting, F. (2005). Gothic. New York: Routledge.

Brantlinger, P. (2006). Imperial Gothic. In Teaching the Gothic. Powell, A. \& Smith, A. (eds.). New York: Palgrave Macmillan, p. 153-168. 
Brien, D.L. (2015). Unsettled and destabilising life writing. The Gothic memoir. In New directions in $21^{\text {st }}$ century Gothic. Piatti-Farnell, L. \& Brien, D.L. (eds.). LondonNew York: Routledge, Taylor \& Francis Group, p. 146-163.

Burke, E. (1998). A philosophical enquiry into the origin of our ideas of the sublime and beautiful. Oxford: OUP.

Carroll, N. (1990). The philosophy of horror. Paradoxes of the heart. New YorkLondon: Routledge.

Cavallaro, D. (2002). The Gothic vision: Three centuries of horror, terror and fear. London-New York: Continuum International Publishing Group.

Chameyev, A.A. (2009). A rendezvous with ghosts. In English ghost stories. Antonov, S. \& Chameyev, A. (eds.). Saint Petersburg: Azbuka-klassika, p. 5-16. / Chameyev A.A. Randevu s prizrakami. In Anglijskiye rasskazy o privideniyakh. Antonov S., Chameyev A. (reds.). Sankt-Peterburg: Azbuka-klassika, s. 5-16. I Чамеев А.А. Рандеву с призраками. In Английские рассказы о привидениях. Антонов С., Чамеев А. (ред.). Санкт-Петербург: Азбука-классика, с. 5-16.

Cherry, B. (2009). Horror. London-New York: Routledge.

Clayton, C.T. (2017). Gothic stories within stories. Frame narratives and realism in the genre, 1790-1900. Jefferson: McFarland \& Company.

Clüver, C. (2007). Intermediality and interarts studies. In Changing borders: Contemporary positions in intermediality, 1, p. 19-39.

Costantini, M. (2003). Crossing boundaries: The revision of Gothic paradigms in "Heat and Dust". In Empire and the Gothic. The politics of genre. Smith, A. \& Hughes, W. (eds.). New York: Palgrave Macmillan, p. 155-172.

Crawford, J. (2015). Gothic fiction and the evolution of media technology. In Technologies of the Gothic in literature and culture: Technogothics. Edwards, J.D. (ed.). New York: Palgrave Macmillan, p. 35-48.

Curtius, E.R. (1953). European literature and the Latin Middle Ages. New York: Bollingen Foundation. 
Danto, A. (2002). Analytical philosophy of history. Moscow: Ideya-Press. I Danto A. Analiticheskaya filosofiya istorii. Moskva: Ideya-Press. / Данто А. Аналитическая философия истории. Москва: Идея-Пресс.

Davis, D.S. (2006). Introduction. In Strange tales by Rudyard Kipling. Davis, D.S. (ed.). Ware: Wordsworth Editions, p. vii-xiii.

Davis, D.S. (2000). Introduction. In Tales of unease by Sir Arthur Conan Doyle. Davis, D.S. (ed.). Ware: Wordsworth Editions, p. vii-xiv.

Demata, M. (2003). Discovering Eastern horrors: Beckford, Maturin, and the discourse of travel literature. In Empire and the Gothic. The politics of genre. Smith, A. \& Hughes, W. (eds.). New York: Palgrave Macmillan, p. 13-35.

Dugin, A.G. (2002). Foundations of science: Paradigmatic evolution. Moscow: Arktogeya-tsentr. / Dugin A.G. Evolyutsiya paradigmal'nykh osnovanij nauki. Moskva: Arktogeya-tsentr. / Дугин А.Г. Эволюиия парадигмальныхх оснований науки. Москва: Арктогея-центр.

Dugin, A.G. (2009a). Jean Parvulesco: All that approaches the essence splits in two... In A Portuguese servant. Fragments from the dictionary. Filatova, T. (ed.). Saint Petersburg: Amfora, p. 5-10. / Dugin A.G. Zhan Parvulesko: Vsyo, chto priblizhayetsia k suschnosti, razdvaivayetsia... In Portugal'skaya sluzhanka. Otryvki iz dnevnika. Filatova T. (red.). Sankt-Peterburg: Amfora, s. 5-10. I Дугин А.Г. Жан Парвулеско: Все, что приближается к сущности, раздваивается... In Португальская служанка. Отрывки из дневника. Филатова Т. (ред.). Санкт-Петербург: Амфора, с. 5-10.

Dugin, A.G. (2009b). Post-philosophy. Three paradigms in the history of thought. Moscow: "Yevrazijskoye dvizheniye". / Dugin A.G. Postfilosofiya. Tri paradigmy $v$ istorii mysli. Moskva: "Yevrazijskoye dvizheniye". / Дугин А.Г. Постфилософия. Три парадигмы в истории мысли. Москва: "Евразийское движение". 
Edwards, J.D. (2003). Gothic passages. Racial ambiguity and the American Gothic. Iowa City: University of Iowa Press.

Fitzgerald, L. (2006). Romantic Gothic. In Teaching the Gothic. Powell, A. \& Smith, A. (eds.). New York: Palgrave Macmillan, p. 48-62.

Foucault, M. (1978). The history of sexuality: Introduction. The will to knowledge. New York: Pantheon Books.

Gelder, K. \& Weaver, R. (2007). The colonial Australian Gothic. Introduction. In The anthology of colonial Australian Gothic fiction. Gelder, K. \& Weaver, R. (eds.), Melbourne: Melbourne University Publishing, p. 1-11.

Genette, G. (1997). Palimpsests: Literature in the second degree. Lincoln: University of Nebraska Press.

Georgieva, M. (2013). The Gothic child. Berlin: Springer.

Golovin, Ye.V. (2003). Approaching the Snow Queen. Moscow: Arktogeya-tsentr. / Golovin Ye.V. Priblizheniye k Snezhnoj Koroleve. Moskva: Arktogeya-tsentr. / Головин Е.В. Приближение к Снежной Королеве. Москва: Арктогея-центр. Guénon, R. (2008). The crisis of the modern world. Moscow: Exmo. / Genon R. Krizis sovremennogo mira. Moskva: Exmo. / Генон Р. Кризис современного мира. Москва: Эксмо.

Hansen, J. (2009). Terror and Irish modernism. The Gothic tradition from Burke to Beckett. New York: SUNY Press.

Hearn, L. (2006). Kwaidan: Ghost stories and strange tales of old Japan. New York: Dover Publications, Inc.

Hegel, G. W. F. (2010). The science of logic. Cambridge: CUP.

Hegel, G.W.F. (1937). Science of logic. Works. Moscow: Gosudarstvennoye sotsial'no-ekonomicheskoye izdatel'stvo. Vol. V. / Hegel' G.V.F. Nauka logiki. Sochineniya. Moskva: Gosudarstvennoye sotsial'no-ekonomicheskoye izdatel'stvo. Т. V. / Гегель Г.В.Ф. Наука логики. Сочинения. Москва: Государственное социально-экономическое издательство. Т. V. 
Horner, A. \& Zlosnik, S. (1998). Daphne du Maurier: Writing, identity and the Gothic imagination. London: Macmillan Press Ltd.

Horner, A. \& Zlosnik, S. (2006). Female Gothic. In Teaching the Gothic. Powell, A. \& Smith, A. (eds.). New York: Palgrave Macmillan, p. 107-121.

Ihina, Z.A. (2017a). Polymorphous narrative: Intermedial transformations of the fictional text in the Gothic tradition. In Theoretical and didactic philology, 25, p. 129-137. / Ihina Z.A. Polimorfnyj narrative: Intermedialnyye transformatsii khudozhestvennogo teksta $\mathrm{v}$ goticheskoj traditsii. In Teoretychna $i$ dydaktychna filolohiya, 25, s. 129-137. / Игина 3.А. Полиморфный нарратив: Интермедиальные трансформации художественного текста в готической традиции. In Теоретична і дидактична філологія, 25, с. 129-137.

Ihina, Z.A. (2017b). Topoi of the Gothic narrative in the light of the European cultural universals. In Scientific proceedings of Kirovohrad State Pedagogical University, 153, p. 92-98. / Ihina Z.A. Topika goticheskogo narrativa skvoz' prizmu yevropejskikh universalij. In Naukovi zapysky Kirovohrads'koho derzhavnoho pedahohichnoho universytetu, 153, s. 92-98. / Игина 3.А. Топика готического нарратива сквозь призму европейских культурных универсалий. In Наукові записки Кіровоградського державного педагогічного університету, 153, с. 92-98.

Ihina, Z. (2015). Polymorphous narrative of Gothic tradition in linguistic perspective: Comparing fiction and opera libretto. In Advances in language and literary studies, 6 (3), p. 77-82. DOI: 10.7575/aiac.alls.v.6n.3p.77

Ihina, Z. (2017). The topos "revenge" in the Gothic narrative "A legend of the Nightfort": Ways of crystallization. In Lege artis. Language yesterday, today, tomorrow. The journal of University of SS Cyril and Methodius in Trnava. Warsaw: De Gruyter Open, II (1), June 2017, p. 90-127. DOI: 10.1515/lart-2017-0003 Inverso, M.-B. (1990). The Gothic impulse in contemporary drama. Theater and dramatic studies. V. 63. Ann Arbor: UMI Research Press. 
Karschay, S. (2015). Degeneration, normativity and the Gothic at the fin de siècle. New York: Palgrave Macmillan.

King, S. (1983). DanSe Macabre. New York: Berkley Books.

Kipling, R. (2006). Strange tales. Ware: Wordsworth Editions.

Kristeva, J. (1982). Powers of horror. An essay of abjection. New York: Columbia University Press.

Ledoux, E.M. (2013). Social reform in Gothic writing. Fantastic forms of change, 1764-1834. New York: Palgrave Macmillan.

Lloyd-Smith, A. (2006). American Gothic. In Teaching the Gothic. Powell, A. \& Smith, A. (eds.). New York: Palgrave Macmillan, p. 136-153.

Lipinskaya, A.A. (2011). The game on the dark side. In The cursed island. Gothic stories. Rogovskaya, N. (ed.). Saint Petersburg: Azbuka-Attikus, p. 5-16. I Lipinskaya A.A. Igra na tyomnoj storone. In Proklyatyj ostrov. Goticheskiye rasskazy. Rogovskaya N. (otv. za vypusk). Sankt-Peterburg: Azbuka-Attikus, s. 516. / Липинская А.А. Игра на темной стороне. In Проклятый остров. Готические рассказы. Роговская Н. (отв. за выпуск). Санкт-Петербург: Азбука-Аттикус, с. 5-16.

Lovecraft, H.P. (1973). Supernatural horror in literature. New York: Dover Publications.

Luckhurst, R. (2015). Biomedical horror: The new death and the new undead. In Technologies of the Gothic in literature and culture: Technogothics. Edwards, J.D. (ed.). New York: Palgrave Macmillan, p. 84-99.

Marsh-Russel, P. (2006) Introduction. In Uncanny stories of May Sinclair. MarshRussel, P. (ed.). Ware: Wordsworth Editions, p. 7-22.

MacArthur, S. (2015). Gothic science fiction (1818 to the present). New York: Palgrave Macmillan.

McArdle, M. (2014). The readers' advisory guide to genre blends. Chicago: The American Library Association. 
McEvoy, E. (2013). Gothic tourism. In The Gothic world. Byron, G. \& Townshend, D. (eds.). London: Routledge, p. 476-487.

McHale, B. (1987). Postmodernist fiction. London: Routlege.

Menegaldo, G. (2011). The esoteric metalanguage serving the fantastic in H.P. Lovecraft's works. In Necronomicon. The "Grimoire" collection. Kryukov, V. (ed.). Moscow: Enigma, p. 483-510. / Menegal'do Zh. Ezotericheskij metayazyk na sluzhbe fantasticheskogo nachala v tvorchestve Kh.F. Lavkrafta. In Nekronomikon. Kollektsiya "Grimuar". Kryukov V. (red.). Moskva: Enigma, s. 483-510. / Менегальдо Ж. (2011). Эзотерический метаязык на службе фантастического начала в творчестве Х.Ф. Лавкрафта. In Некрономикон. Коллекиия "Гримуар". Крюков В. (ред.). Москва: Энигма, с. 483-510.

Milbank, A. (1992). Daughters of the house. Modes of the Gothic in Victorian fiction. London: The Macmillan Press.

Modern Greek dictionary (1980). Khorikov, I.P. \& Malev, M.G. (eds.). Moscow: Russkij yazyk. / Novogrechesko-russkij slovar'. Khorikov I.P., Malev M.G. (red.). Moskva: Russkij jazyk. / Новогреческо-русский словарь. Хориков И.П., Малев М.Г. (ред.). Москва: Русский язык.

Morgan, J. (2002). Biology of horror: Gothic literature and film. CarbondaleEdwardsville: Southern Illinois University Press.

Nibbrig, K.L.H. (2005). Aesthetics of death. Saint Petersburg: Izdatel'stvo Ivana Limbakha / Nibbrig K.L.H. Estetika smerti. Sankt-Peterburg: Izdatel'stvo Ivana Limbakha / Ниббриг К.Л.Х. Эстетика смерти. Санкт-Петербург: Издательство Ивана Лимбаха.

Nietzsche, F.W. (1968). The will to power. New York: Vintage Books.

Peaty, G. (2015). Rock hard: Gargoyles in contemporary Gothic romance. In New directions in $21^{\text {st }}$ century Gothic. Piatti-Farnell, L. \& Brien, D.L. (eds.). London-New York: Routledge, Taylor \& Francis Group, p. 54-71. 
Perkins Gilman, C. (1998). The yellow wallpaper. In The yellow wall-paper and other stories. Shulman, R. (ed.). Oxford: OUP, p. 3-20.

Perry, D.R., \& Sederholm, C.H. (2009). Poe, "The house of Usher", and the American Gothic. New York: Palgrave Macmillan.

Plutarch. (2013). Theseus. In Plutarch's lives. Vol. I. Clough, A.H. (ed.). New York: Cosimo, p. 1-36.

Poltoratskaya, N.I. (1992). Foreword. In The nail of destiny. Zenyuk, T.N. \& Kriazhevskikh, G.I. (eds.). Saint Petersburg: Lenizdat, p. 3-17. / Poltoratskaya N.I. Predisloviye. In Nogotok sud'by. Zenyuk T.N., Kriazhevskikh G.I. (red.). SanktPeterburg: Lenizdat, s. 3-17. / Полторацкая Н.И. Предисловие. In Ноготок cудьбы. Зенюк Т.Н., Кряжевских Г.И. (ред.). Санкт-Петербург: Лениздат, с. 3-17.

Punter, D. \& Byron, G. (2004). The Gothic. Hoboken: Blackwell Publishing Ltd. Punter, D. (2001). Gothic modernisms. In Hungry ghosts and foreign bodies. Smith, A. \& Wallace, J. (eds.). New York: Palgrave Macmillan, p. 11-29.

Radcliffe, A. (2004). On the supernatural in poetry. In Fantastic literature: A critical reader. Sandner, D. (ed.). Westport: Greenwood Publishing Group, p. 4151.

Rajewsky, I.O. (2005). Intermediality, intertextuality, and remediation. A literary perspective on intermediality. In Intermedialites, 6, p. 43-64.

Roberts, M. (1990). Gothic immortals. The fiction of the brotherhood of the Rosy Cross. London: Routledge.

Romano, A. What is Dreadpunk? A quick guide to a new subgenre. Available at: https://www.dailydot.com/parsec/dreadpunk-dragoncon-gothic-horror-fantasy/

Ryan, M.-L. \& Thon, J-N. (2014). Storyworlds across media: Introduction. In Storyworlds across media. Toward a media-conscious narratology. Ryan, M.-L. \& Thon, J.-N. (eds.). Lincoln-London: University of Nebraska Press, p. 1-25. 
Savoy, E. (1998). The face of the tenant: A theory of American Gothic. In American Gothic. New interventions in a national narrative. Martin, R.K. \& Savoy, E. (eds.). Iowa City: University of Iowa Press, p. 3-20.

Schmid, W. (2010). Narratology: An introduction. Berlin-New York: Walter de Gruyter GmbH \& Co. KG.

Schopenhauer, A. (2010). The world as will and representation. Exeter: David \& Charles Publishers.

Scott, W. (1992). About Walpole's "The castle of Otranto". In The devil in love. Zharikov, V.I. \& Mishchenko, V.G. (eds.). Minsk: Moka-imidzh, p. 181-196. I Scott W. O "zamke Otranto" Uolpola. In Vlyublyonnyj dyavol. Zharikov V.I., Mishchenko V.G (red.). Minsk: Moka-imidzh, s. 181-196. / Скотт В. O "замке Отранто" Уолпола. In Влюбленный дьявол. Жариков В.И., Мищенко В.Г. (ред.). Минск: Мока-имидж, с. 181-196.

Shanahan, J. (2014). Suffering rebellion: Irish Gothic fiction, 1799-1830. In Irish Gothics. Genres, forms, modes, and traditions, 1760-1890. Morin, C. \& Gillespie, N. (eds.). New York: Palgrave Macmillan, p. 74-94.

Smith, A. (2007). Gothic literature. Edinburgh: Edinburgh University Press Ltd.

Snodgrass, M.E. (2005a). Femme fatale. In Encyclopedia of Gothic literature. Snodgrass, M.E. (compiler). New York: Facts on File, p. 120-121.

Snodgrass, M.E. (2005b). Gothic novel. In Encyclopedia of Gothic literature. Snodgrass, M.E. (compiler). New York: Facts on File, p. 156-157.

Snodgrass, M.E. (2005c). Schauer-Romantik. In Encyclopedia of Gothic literature. Snodgrass, M.E. (compiler). New York: Facts on File, p. 306-307.

Spengler, O. (1998). The decline of the West. Moscow: Mysl'. / Shpengler O. Zakat Yevropy. Moskva: Mysl'. / Шпенглер О. Закат Европьы. Москва: Мысль.

Spooner, C. (2006). Contemporary Gothic. London: Reaktion books.

Stefanov, Yu. (2011). The self-portrait against the infernal background. In Necronomicon. Kryukov, V. (ed.). Moscow: Enigma, p. 20-25. / Stefanov Yu. 
Avtoportret na fone infernal'nogo pejzazha. In Nekronomikon. Kryukov V. (red.). Moskva: Enigma, s. 20-25. / Стефанов Ю. Автопортрет на фоне инфернального пейзажа. In Некрономикон. Крюков В. (ред.). Москва: Энигма, с. 20-25.

Summers, M. (1964). The Gothic quest: A history of the Gothic novel. New York: Russell \& Russell.

Taylor, N. (2015). Impersonating spirits: The paranormal entertainer and the dramaturgy of the Gothic séance. In New directions in $21^{\text {st }}$ century Gothic. PiattiFarnell, L. \& Brien, D.L. (eds.). London-New York: Routledge, Taylor \& Francis Group, p. 163-175.

Todorov, T. (1975). The fantastic: A structural approach to a literary genre. IthacaNew York: Cornell University Press.

Toolan, M. (2006). Narrative: Linguistic and structural theories. In Encyclopaedia of language and linguistics. Oxford: Elsevier, p. 459-473.

Wasson, S. (2015). Recalcitrant tissue: Cadaveric organ transplant and the struggle for narrative control. In Technologies of the Gothic in literature and culture: Technogothics. Edwards, J.D. (ed.). New York: Palgrave Macmillan, p. 99-113.

Watt, J. (2004). Contesting the Gothic. Fiction, genre and cultural conflict. Cambridge: Cambridge University Press.

Wester, M.L. (2012). African American Gothic. Screams from shadowed places. New York: Palgrave Macmillan.

Williams, A. (1995). Art of darkness: A poetics of Gothic. Chicago-London: The University of Chicago Press.

Wisker, G. (2006). Postcolonial Gothic. In Teaching the Gothic. Powell, A. \& Smith, A. (eds.). London-New York: Palgrave Macmillan, p. 168-182.

Wisker, G. (2016). Contemporary women's Gothic fiction: Carnival, hauntings and vampire kisses. London: Palgrave Macmillan.

Wolf, W. (2002). Intermediality revisited. Reflections on word and music relations in the context of a general typology of intermediality. In Word and music studies. 
Essays in honor of S.P. Scher. Bernhart, W. \& Aspden, S. (eds.). Amsterdam-New York: Rodopi, p. 13-35.

Wolf, W. (2007). Description as a transmedial mode of representation: General features and possibilities of realization in painting, fiction and music. In Description in literature and other media. Wolf, W. \& Bernhart, W. (eds.). New York: Rodopi, p. 1-91.

Wolfreys, J. (2006). Victorian Gothic. In Teaching the Gothic. Powell, A. \& Smith, A. (eds.). London-New York: Palgrave Macmillan, p. 62-78.

Zalomkina, G.V. (2011). The Gothic myth: A literary phenomenon. Thesis for the doctor degree in philology. Speciality 10.01.08 - Theory of literature. Textology. Samara: Samara State University. / Zalomkina G.V. Goticheskij mif kak literaturnyj fenomen. Dissertatsiya na soiskaniye uchyonoj stepeni doktora filologicheskikh nauk. Spetsial'nost' 10.01.08 - teoriya literatury. Tekstologiya. Samara: Samarskij gosudarstvennyj universitet. / Заломкина Г.В. Готический миф как литературный феномен. Диссертация на соискание ученой степени доктора филологических наук. Специальность 10.01 .08 - теория литературы. Текстология Самара: Самарский государственный университет. Zharinov, Ye.V. (2000). Historical and literary background of the mass belleslettres literature. Thesis for the doctor degree in philology. Specialities: $10.01 .01-$ Russian literature, 10.01.05 - Literature of Europe, America, and Australia. Moscow: Moscow State University of Education. / Zharinov Ye.V. Istorikoliteraturnyye korni massovoj belletristiki. Dissertatsiya na soiskaniye uchyonoj stepeni doktora filologicheskikh nauk. Spetsial'nosti: 10.01.01 - russkaya literatura, 10.01.05 - literatura narodov Yevropy, Ameriki i Avstralii. Moskva: Moskovskij gosudarstvennyj otkrytyj pedagogicheskij universitet. / Жаринов Е.В. Историколитературные корни массовой беллетристики. Диссертация на соискание ученой степени доктора филологических наук. Специальности: 10.01.01 русская литература, 10.01.05 - литература народов Европы, Америки и 
Австралии. Москва: Московский государственный открытый педагогический университет.

Zharinov, Ye.V. (2016). Lectures about literature. The dialogue of epochs. Moscow: AST. / Zharinov Ye.V. Lektsii o literature. Dialog epokh. Moskva: AST. / Жаринов Е.В. Лекции о литературе. Диалог эпох. Москва: АСТ.

\begin{tabular}{|c|c|l|}
\hline $\begin{array}{c}\text { Contact data } \\
\text { Zoia Ihina }\end{array}$ & \multicolumn{1}{c|}{ Fields of interest } \\
CSc. (Philology), \\
Postdoctoral student \\
German Language and \\
Translation Department, \\
Kyiv National Linguistic \\
University, 73, Velyka \\
Vasyl'kivs'ka St., Kyiv, \\
03680, Ukraine. email: \\
ihina.zoia@gmail.com
\end{tabular}

\section{Résumé}

Polymorphous Gothic narratives are stories based on the event of confrontation between the known and the unknown and realized in the same or different media (usually in fiction and film). The term intermediality signifies transferring any narrative into another medium, and the term polymorphism concerns the inner quality of a concrete narrative to be implemented within the same medium or in different ones. Polymorphism has depth and scope. The former is a homomedial shift of a concrete Gothic narrative within one medium, and the latter is its heteromedial interpretation. Since any Gothic narrative reproduces an original story while being transferred into other media, the main interpreter's object is the event retranslated either with no changes or with modifications that influence the understanding of the event and the original story. The event is retranslated into other media in authentic (detailed or reduced) and modified (transformed or transmuted) 
modes. Authentic retranslation redoes the event without significant changes. Its detailed type retains all major characters and plotlines. Reduced retranslation shortens the number of characters and renders only chosen plotlines. In case of modified retranslation, interpreters reconsider the original event to such a degree that the result acquires features of an independent conception, though based on some existing Gothic narrative. According to the transformation of the event, the modified retranslation presupposes changing the time and place as well as adding some extra characters to the original narrative. The event transmutation of the event concerns changes in the essence of the Gothic narrative and modifies, accordingly, the original idea. The suggested classification of polymorphous Gothic narratives is based on the mode of retranslation confining itself to the pattern "the original $\rightarrow$ adaptation (transponent)". All variants of interpreting a particular narrative make up its polymorphous matrix.

Key words: event, Gothic, intermediality, narrative, polymorphism, retranslation.

Article was received by the editorial board 09.01.18;

Reviewed 07.02.18. and 19.03.18.

Similarity Index 2\% 